\title{
Seroprevalence and Risk Factors of Leishmania infantum in Canine Shelters in Bucaramanga Metropolitan Area and Barrancabermeja, Andean Region Santander, Colombia
}

\author{
Florez-Muñoz Angel Alberto ${ }^{1, *}$, Trejos Juanita ${ }^{2}$, Rosas-Martinez Ariel ${ }^{3}$, Beltrão-Molento Marcelo ${ }^{4}$, \\ Quintero Luis ${ }^{1}$ and Pinilla-Leon Juan ${ }^{1}$
}

\begin{abstract}
${ }^{1}$ Universidad de Santander, Facultad de Ciencias Agrícolas y Veterinarias, Bucaramanga, Colombia ${ }^{2}$ Universidad de Santander, Facultad de Ciencias Médicas y de la Salud, Bucaramanga, Colombia ${ }^{3}$ Programa de Medicina Veterinaria. UNIPAZ, Barrancabermeja, Santander, Colombia

${ }^{4}$ Universidade Federal do Paraná, Departamento de Medicina Veterinária, UFPR. Curitiba, PR, Brazil

*Corresponding author: ang.florez@ mail.udes.edu.co
\end{abstract}

Article History: 21-321 Received: 31-May-21 Revised: 03-Jul-21 Accepted: 22-Jul-21
ABSTRA C T
Leishmaniasis is a protozoan disease caused by Leishmania spp. and transmitted by sand-flies to different hosts. In
Colombia, Leishmania has been reported in dogs from rural and urban areas. The aims of the investigation were to
define the risk factors of Leishmania infantum ( $L$. infantum) in canine shelters in municipalities of the Bucaramanga
metropolitan area, and Barrancabermeja municipality, and to determine the seroprevalence for $L$. infantum. An
observational study was carried out. The samples were analyzed with ELISA antibody anti- $L$. infantum (n=282).
Epidemiological data about the risk factors were achieved by conducting a survey in these dog shelters (14 questions).
The data were analyzed to determine the association between the variables under study and the results of the ELISA
test. The seroprevalence of $L$. infantum was $4.3 \%$ in the Bucaramanga metropolitan area and zero (0/48) in
Barrancabermeja. The dogs sleeping outdoor was associated with the odds for Leishmania in Bucaramanga (P=0.04).
We have demonstrated the seroprevalence of $L$. infantum in canine shelters in the Bucaramanga metropolitan area,
possibly by the high contact of dogs with Lutzomyia spp. vectors. This data may help to identify risk factors in similar
geographical areas, assisting to design new control strategies.

Key words: Risk factors, Seroprevalence, Leishmania.

\section{INTRODUCTION}

Leishmaniasis is a disease caused by the protozoa Leishmania spp. transmitted by the sand-flies Lutzomyia (Lu.) longipalpis and Lu. evansi in the Americas. The disease is ubiquitous in dogs and other hosts, including humans, being endemic in continents Asian, African, Europe, and the countries of the Latin American continent (LATAM) where vectors are found in suitable environmental conditions. Leishmania spp. cause visceral, mucocutaneous, and cutaneous leishmaniasis (Meleau and Hnilico 2006; Bowman 2014). A large number of canine infections in South America are produced by $L$. infantum and $L$. braziliensis, but their distribution is probably higher than it is recorded (Dantas-Torres 2009). In some LATAM countries, the canines are observed as the essential domestic accumulators of $L$. infantum having a high-risk exposure to Leishmania (Feliciangeli et al. 2005; Dantas-Torres and Brandão-Filho 2006; Fernandez et al. 2006; Dantas-Torres 2007; Romero et al. 2009; Barroso et al. 2015; Acosta et al. 2015; Rivero et al. 2018). Moreover, some other studies have observed that dogs may not play a major role in the epidemiology of the disease (Travi et al. 1992; Rosypal et al. 2007).

In Colombia, L. infantum has been reported in dogs from rural and urban areas. In Piedecuesta, L. chagasi was detected in dogs using a serological test (Márquez 2004). L. infantum antibodies were also observed in dogs from the Tolima Department (Romero et al. 2008; Romero et al. 2009). Fernández et al. (2002) and Fernández et al. (2006) have determined the seroprevalence of $L$. infantum chagasi from dogs from the Huila Department. Similar

Cite This Article as: Alberto FMA, Juanita T, Ariel RM, Marcelo BM, Luis Q and Juan PL, 2022. Seroprevalence and risk factors of Leishmania infantum in canine shelters in Bucaramanga Metropolitan area and Barrancabermeja, Andean Region Santander, Colombia. International Journal of Veterinary Science 11(2): 175-182. https://doi.org/10.47278/journal.ijvs/2021.104 
data were found from Neiva, determining a $6.1 \%$ prevalence of $L$. infantum in dogs (Zambrano et al. 2015). A study in Bogotá found a low $(1.6 \%)$ L. infantum seroprevalence in dogs (Rosypal et al. 2007). Also, in a visceral leishmaniasis-endemic area of Cundinamarca, an investigation showed dogs that were serologically positive by an enzyme-linked immunosorbent assay (ELISA) which used soluble Leishmania chagasi (Travi et al. 2001).

In Bucaramanga, Colombia a dog was reported with L. infantum antibodies (Cáceres 2020). Serum samples of dogs stored at the Biobank of the National Institute of Health of Colombia from a previous outbreak of visceral leishmaniasis (VL) were found (100\%) positive to $L$. infantum (Herrera et al. 2018; Herrera et al. 2019). In the Department of Sucre, L. infantum was determined in dogs by serology and PCR (Rivero et al. 2018; Rivero et al. 2020). Arbeláez et al. (2020) also reported an urban case of canine visceral leishmaniasis in Cali, using a primerspecific PCR diagnostic.

In Argentina, L. infantum was observed in a $6.2 \%$ of dogs (Acosta et al. 2015; Barroso et al. 2015). In Petrolina and Jequié, in the state of Bahia, Brazil, the seroprevalence of $L$. infantum was associated with the animal gender, breed, age group, and hair length (Moreira et al. 2003; Queiroz et al 2009; Pacheco et al. 2013; Barbosa et al. 2015; Araujo et al. 2016; Fujimori et al. 2016). In Venezuela, L. infantum was found in $2.1 \%$ of dogs by PCR detection (Feliciangeli et al. 2005; Rivas et al. 2020). L. infantum was also reported in Mexico from 6.1 to $11.9 \%$ in dogs (Arjona et al. 2012; López et al. 2012). Reports of the low incidence of $L$. infantum in dogs (IFA titers $\geq 1: 128$ and PCR) came also from the United States of America (Gaskin et al. 2002; Schaut et al. 2015; de Almeida et al. 2020).

Studies have been carried out in different regions of Colombia that have reported Leishmania species infecting humans and dogs in the same geographic area (Herrera et al. 2018; Herrera et al. 2019). Due to one health related problems of leishmaniasis, more epidemiological investigations should be carried out to determine $L$. infantum prevalence and associated risk factors in dog populations from Colombia (Rosypal et al. 2007). However, the routine surveillance of leishmaniasis in dogs is not regularly carried out in the country, and therefore, the assessment of the spread of the infection has not yet been fully elucidated (Herrera et al. 2018). In this way, the identification of risk factors of Leishmania disease in $\operatorname{dog} s$ is important to establish and carry out adequate prevention strategies in the dog population that could lead to improved and successful control programs of zoonotic visceral leishmaniasis (Moreira et al. 2003). Despite the above situation, there are no scientific reports that have assessed the epidemiological situation of this disease in the Andean region of Santander. The aims of investigation were to define the risk factors of Leishmania infantum in canine shelters in the municipalities of the Bucaramanga metropolitan area, and Barrancabermeja, Department of Santander. An additional, objective was the determination of seroprevalence for Leishmania infantum.

\section{MATERIALS AND METHODS}

\section{Ethical Considerations}

The present investigation was approved by the Committee of Ethics and Research of the University of Santander, Colombia (protocol no. CIF0308-19). Owners of the dogs participating in the project were informed of the research objectives and signed the 'Informed Consent Form' before all sample collections.

\section{Study Design}

A cross-sectional and descriptive investigation was carried out during September to December 2019 in dog shelters located in the Bucaramanga $\left(7^{\circ} 07^{\prime} 07^{\prime \prime} \mathrm{N}\right.$ $\left.73^{\circ} 06^{\prime} 58^{\prime \prime} \mathrm{W}\right), \quad$ Floridablanca $\left(7^{\circ} 04^{\prime} 11^{\prime \prime} \mathrm{N}-73^{\circ} 05^{\prime} 52^{\prime \prime} \mathrm{W}\right)$, Girón $\left(7^{\circ} 04^{\prime} 23^{\prime \prime} \mathrm{N}-73.10^{\prime} 05^{\prime \prime} \mathrm{W}\right)$, Piedecuesta $\left(6^{\circ} 59^{\prime} 19^{\prime \prime} \mathrm{N}\right.$ $\left.73^{\circ} 03^{\prime} 01^{\prime \prime} \mathrm{W}\right)$ and Barrancabermeja $\left(7^{\circ} 4^{\prime} 1^{\prime \prime} \mathrm{N}-73^{\circ} 52^{\prime} 1^{\prime \prime}\right.$ W) (Fig. 1) municipalities Santander Department, Colombia (Gobernación de Santander 2017). The environmental characteristics of the Department of Santander are similar, with an average temperature of $25^{\circ} \mathrm{C}$ and little climatic variation during the year. It is located between 600 and 1700 meters above sea level and with an average annual rainfall of $1040 \mathrm{~mm}$, and $78 \%$ relative humidity. This Department has a geographical area of $1479 \mathrm{~km} 2$. Rainfall is more frequent during the months of October to December (IDEAM 2019).

The period was characterized as rainy with a constant presence of flies and mosquitos (A. Florez Muñoz, Personal communication).

\section{Laboratory Analysis Blood Sampling}

Serum samples were taken applying simple random sampling in each canine shelter and Leishmaniasis was determined using an ELISA antibody anti-Leishmania infantum. Serum samples from canines older than 6 months and living in the shelters for at least 6 months were taken into account. A sample population of 282 was determined applying the model for a known frequency (Thrusfield 2007) with a projected canine seroprevalence of $23 \%$ (Le Pape 1992) and a confidence interval of $95 \%$. The samples were randomly distributed (approx. 30 samples/shelter) with respect to the canine population reported in the municipalities under study (Ministerio de Salud de Colombia 2019).

\section{Serological Analysis}

A $6 \mathrm{~mL}$ whole blood sample was taken by puncture of the cephalic vein in a sterile vacutainer tube with anticoagulant from each canine. These blood samples were centrifuged at $3000 \mathrm{rpm}$ for $10 \mathrm{~min}$, and the serum was transported to $1.5 \mathrm{~mL}$ Eppendorf tubes and stored at $80^{\circ} \mathrm{C}$. The prevalence of leishmaniasis was determined using a commercial indirect enzyme-linked immunosorbent assay (ELISA) test to identify antibody anti-Leishmania infantum (Ingezim LEISHMANIA, Madrid, Spain). The mean of two readings was used to classify samples as positive (ODPK $=0.468)$, negative (ODNK=0.401), or inconclusive (between 0.401 and 0.468). The cut-offs were established following the product guide. All sera with positive results were retested at least once. 
Int J Vet Sci, 2022, 11(2): 175-182.

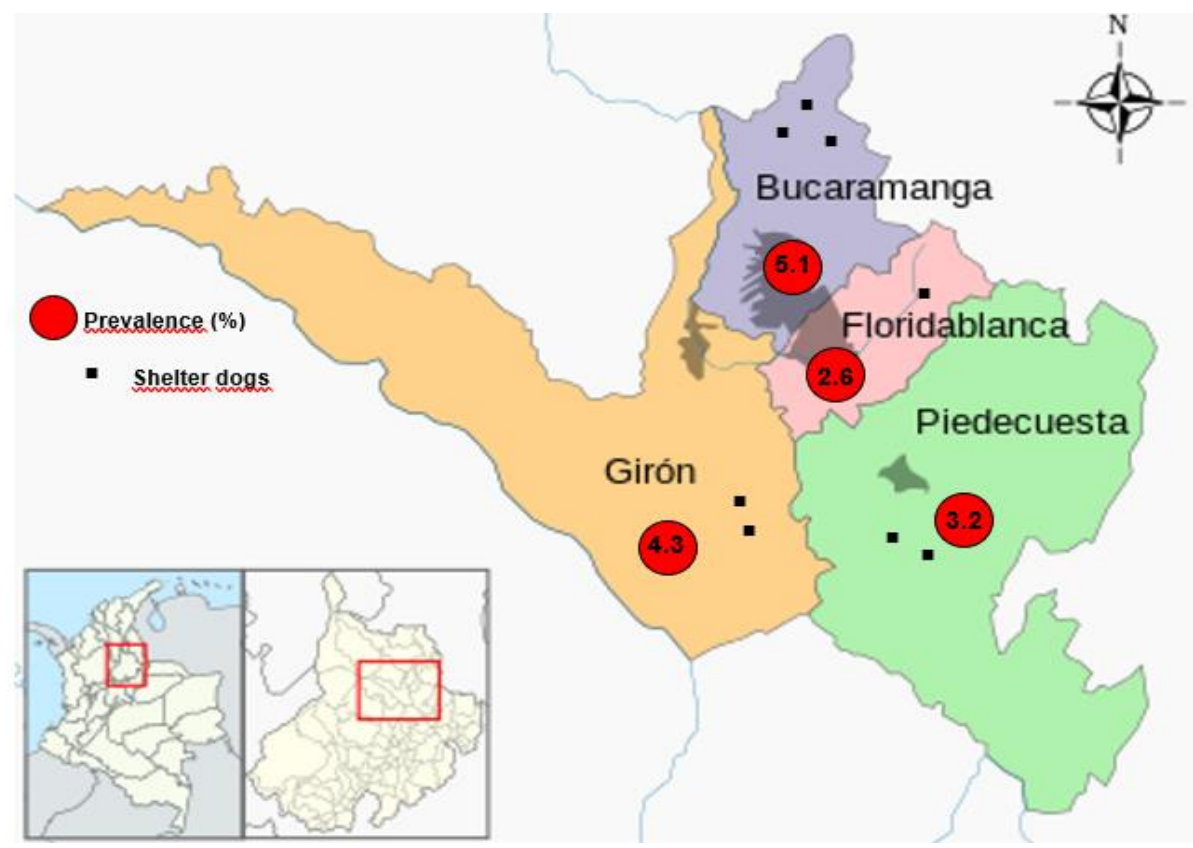

Fig. 1: Map of Bucaramanga metropolitan area where the regions under study, shelters dog visited and the overall prevalence of $L$. infantum are observed. In the Barrancabermeja municipality, one shelters dog was visited and seroprevalence was zero [Source: original map https://es.wikipedia.org/wiki/\%C 3\%81rea metropolitanadeBucara manga]

\section{Risk Factors for Leishmania (Questionnaire)}

Epidemiological data about the risk factors were achieved by conducting a survey in these dog shelters (14 questions) and at the same time, blood samples were taken. The following variables from the survey were considered: municipalities (Bucaramanga, Floridablanca, Girón, Piedecuesta, and Barrancabermeja), gender, dog breed (pure breed/cross breed), age group $(<1$ year, 1 to 5 years, $>5$ years), hair length (short/long hair), mosquito control (yes/no), ectoparasite treatment (yes/no), presence of wild animals (yes/no), dogs sleeping outdoors (yes/no), contact with other animals (yes/no), presence of green areas/trees (yes/no), presence of mosquitoes (yes/no), knowledge of leishmaniasis (yes/no), and the presence of visible clinical signs of leishmaniasis (onychogryphosis, alopecia, mucocutaneous ulcers, and cachexia) (yes/no). A general clinical examination of each dog was performed by veterinarians, taking greater attention to mucocuta-neous problems and the general condition of the patient.

\section{Statistical Study}

The data were analyzed to determine the association between survey variables and results of test ELISA (presence or absence of antibodies of Leishmania infantum) through the Chi-square test. The probability of risk odds ratio (OR) and the confidence intervals of the risk factors were reached employing a univariate logistic regression study, taking as the reference category the one with the lowest probability of risk and leaving the others as study categories (Aguayo and Lora Monge, 2007). The statistical probability level for the study was $\mathrm{P}<0.05$. The data evaluation was carried out using the SPSS 21 program (SPSS 2012).

\section{RESULTS}

Seroprevalence of $L$. infantum was $4.3 \%$ in canine shelters from Bucaramanga, Floridablanca, Girón, Piedecuesta municipalities (Table 1), no statistical association was observed. In the Barrancabermeja
Table 1: Leishmania infantum seroprevalence in dogs by the municipality in the Bucaramanga metropolitan area, Colombia

\begin{tabular}{lccccc}
\hline Variable & $\begin{array}{c}\text { Total } \\
\text { Dogs }\end{array}$ & Dogs $(+)$ & $\begin{array}{c}\text { Prevalence } \\
(\%)\end{array}$ & $\begin{array}{c}\text { P- } \\
\text { value }\end{array}$ & OR \\
\hline Municipality & & & & & \\
Bucaramanga & 118 & 6 & 5.1 & & 1 \\
Piedecuesta & 31 & 1 & 3.2 & & 0.59 \\
Floridablanca & 38 & 1 & 2.6 & & 0.87 \\
Girón & 47 & 2 & 4.3 & 0.91 & 0.68 \\
\hline Overall & 234 & 10 & 4.3 & & \\
\hline
\end{tabular}

$1=$ Reference category. $\mathrm{OR}=$ odds ratio. Statistical significance $(\mathrm{P}<0.05)$.

municipality the seroprevalence of $L$. infantum was zero (0/48). Regarding the results, antibody anti-Leishmania infantum were observed in all municipalities in the Bucaramanga area. No significant difference $(\mathrm{P}>0.05)$ was observed between presence or absence of antibodies to $L$. infantum and the intrinsic variables gender, dog breed, age group, hair length, and extrinsic variables mosquito's control, ectoparasite treatment, wild animal presence, contact with other animals, presence of mosquitoes, presence of green areas/ trees and knowledge of leishmaniasis. Dogs sleeping outdoors was the only variable that showed a statistical association $(\mathrm{P}=0.04)$. The prevalence was higher but not statistically significant $(\mathrm{P}>0.05)$ among females, with an approximate age range of 1 to 5 years old, and short haired dogs (Table 2).

Clinical manifestations were observed in eight seropositive dogs (Fig. 2, 3), while two seropositive dogs were not observed for any clinical signs (Table 5). Table 4 shows the clinical manifestations in the eight seropositive dogs for $L$. infantum antibodies. There were statistically significant differences $(\mathrm{P}<0.01)$ between seropositivity and the clinical signs of the disease, where $2.8 \%$ of seropositive dogs (8/282) showed specific clinical signs. Seroprevalence of $L$. infantum was higher in dogs with clinical symptoms $(2.8 \%)$ than in those without any clinical signs $(0.7 \%)$. Alopecia and ulcers were the most common clinical manifestations. In $83 \%$ (233) of the examined dogs no apparent clinical signs were suggestive of leishmaniasis. 
Int J Vet Sci, 2022, 11(2): 175-182.

Table 2: Logistic regression for risk factor associated with Leishmania infantum seroprevalence in dogs in the Bucaramanga metropolitan area, Colombia (Intrinsic variables)

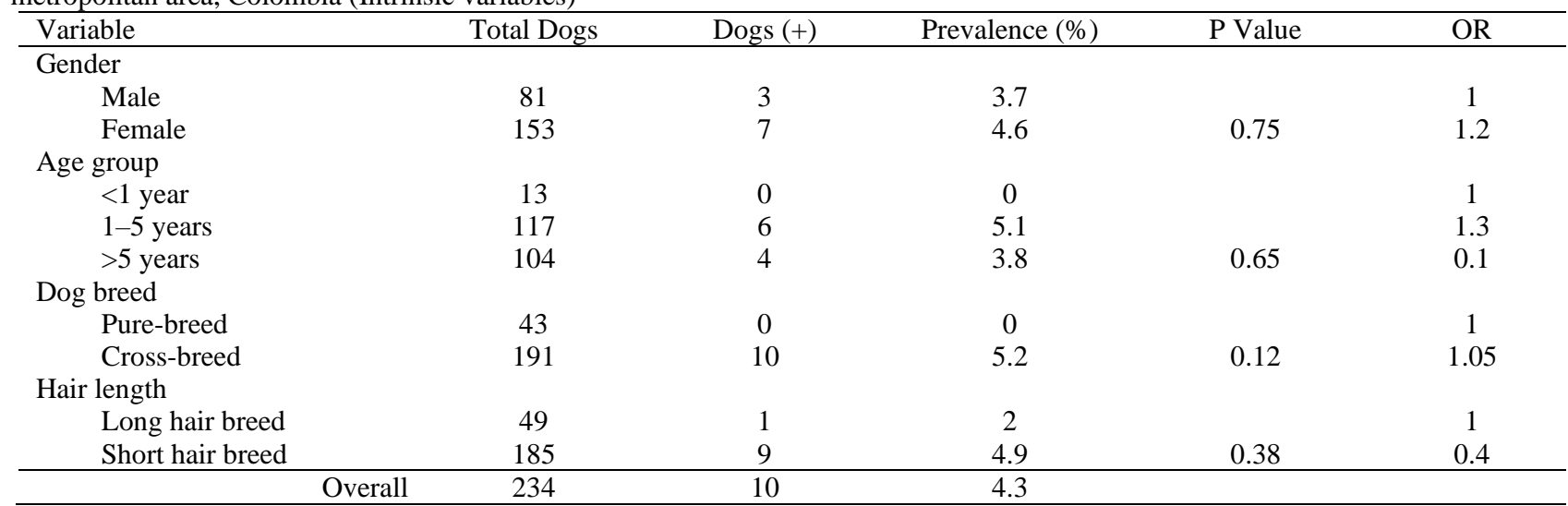

$1=$ Reference category. $\mathrm{OR}=$ odds ratio. Statistical significance $(\mathrm{P}<0.05)$.

Table 3: Logistic regression for risk factor associated with Leishmania infantum seroprevalence in dogs in the Bucaramanga metropolitan area and Barrancabermeja, Colombia (Extrinsic variables)

\begin{tabular}{|c|c|c|c|c|c|}
\hline Variable & $\begin{array}{l}\text { Total } \\
\text { dogs }\end{array}$ & $\begin{array}{c}\text { Dogs } \\
(+)\end{array}$ & $\begin{array}{c}\text { Prevalence } \\
(\%)\end{array}$ & $\begin{array}{c}\mathrm{P}- \\
\text { value }\end{array}$ & OR \\
\hline \multicolumn{6}{|c|}{ Mosquito's control } \\
\hline No & 148 & 4 & 2.7 & & 1 \\
\hline Yes & 134 & 6 & 4.5 & 0.65 & 1.3 \\
\hline \multicolumn{6}{|c|}{$\begin{array}{l}\text { Wild animal } \\
\text { presence }\end{array}$} \\
\hline No & 36 & 0 & 0 & & 1 \\
\hline Yes & 246 & 10 & 4.0 & 0.23 & 1.04 \\
\hline \multicolumn{6}{|c|}{ Dogs sleep outdoor } \\
\hline No & 83 & 0 & 0 & & 1 \\
\hline Yes & 199 & 10 & 5.0 & 0.04 & 2.05 \\
\hline \multicolumn{6}{|c|}{$\begin{array}{l}\text { Contact with other } \\
\text { animals }\end{array}$} \\
\hline No & 78 & 1 & 1.3 & & 1 \\
\hline Yes & 204 & 9 & 4.4 & 0.20 & 0.02 \\
\hline \multicolumn{6}{|c|}{$\begin{array}{l}\text { Ectoparasite } \\
\text { treatment }\end{array}$} \\
\hline No & 58 & 1 & 1.7 & & 1 \\
\hline Yes & 224 & 9 & 4.0 & 0.43 & 2.3 \\
\hline \multicolumn{6}{|c|}{$\begin{array}{l}\text { Presence of } \\
\text { mosquitoes }\end{array}$} \\
\hline No & 13 & 0 & 0 & & 1 \\
\hline Yes & 269 & 10 & 3.7 & 0.47 & 0.99 \\
\hline \multicolumn{6}{|c|}{$\begin{array}{l}\text { Presence of green } \\
\text { area/ trees }\end{array}$} \\
\hline No & 41 & 0 & 0 & & 1 \\
\hline Yes & 241 & 10 & 4.1 & 0.1842 & 0.95 \\
\hline \multicolumn{6}{|c|}{$\begin{array}{l}\text { knowledge of } \\
\text { leishmaniasis }\end{array}$} \\
\hline No & 165 & 5 & 3.0 & & 1 \\
\hline Yes & 117 & 5 & 4.3 & 0.55 & 1.4 \\
\hline Overall & 282 & 10 & 3.6 & & \\
\hline
\end{tabular}

$1=$ Reference category. OR=odds ratio. Statistical significance $(\mathrm{P}<0.05)$.

Table 4: Frequency and prevalence of clinical signs from seropositive dogs for Leishmania infantum antibodies from the Bucaramanga metropolitan area, Colombia

\begin{tabular}{lccc}
\hline $\begin{array}{c}\text { Clinical } \\
\text { Manifestations }\end{array}$ & $\begin{array}{c}\text { No. Total } \\
\text { Dogs }\end{array}$ & $\begin{array}{c}\text { No. } \\
\text { Seropositive }\end{array}$ & $\begin{array}{c}\text { Sero- } \\
\text { prevalence } \\
(\%)\end{array}$ \\
\hline Alopecia & 22 & 3 & 14 \\
Cachexia & 18 & 2 & 12 \\
Diarrhea & 2 & 0 & 0 \\
Respiratory sigs & 2 & 0 & 0 \\
Onychogryphosis & 3 & 1 & 33 \\
Mucocutaneous ulcer & 2 & 2 & 100 \\
\hline
\end{tabular}

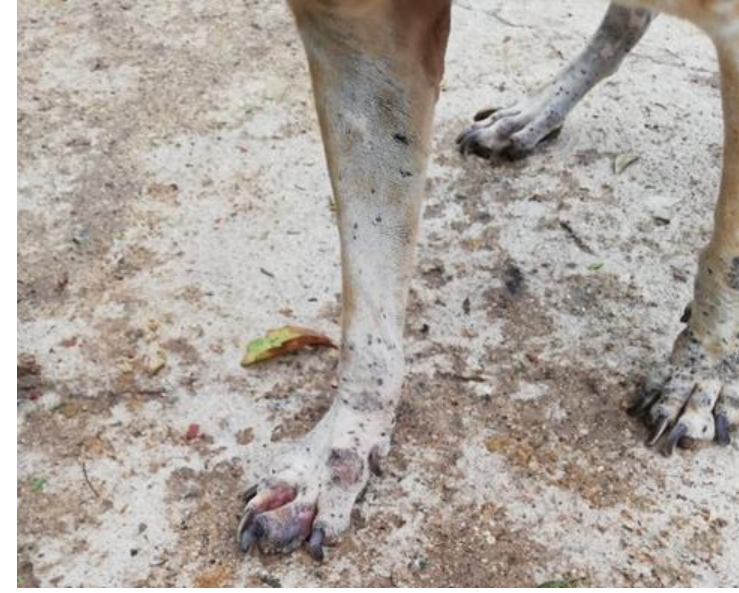

Fig. 2: Onychogryphosis observed in dog.

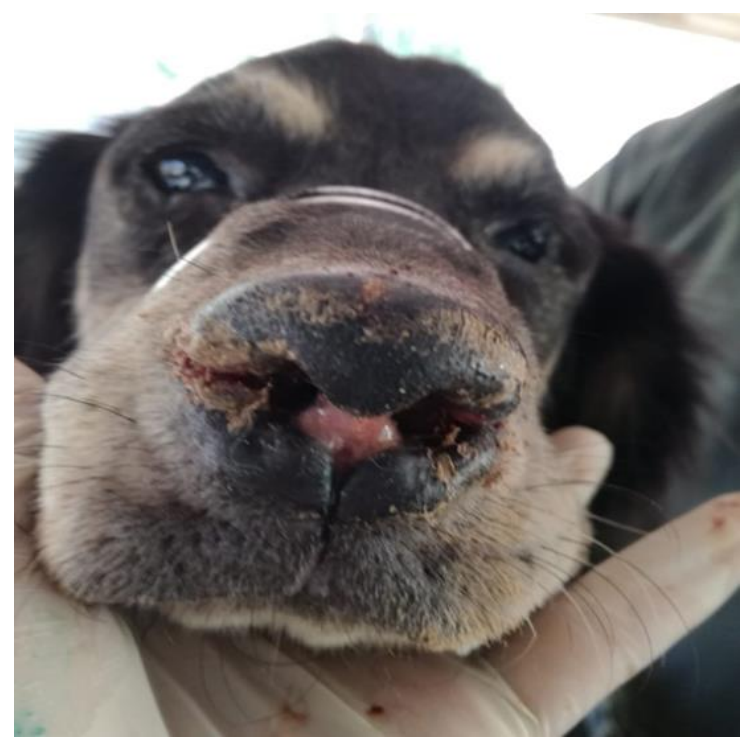

Fig. 3: Mucocutaneous ulcer in the nose in dog.

Table 5: Serological prevalence by ELISA according to the presence or absence of clinical manifestations associated with leishmaniasis

\begin{tabular}{lccc}
\hline Clinical status & $\begin{array}{c}\text { Positive } \\
\text { dogs }\end{array}$ & $\begin{array}{c}\text { Negative } \\
\text { dogs }\end{array}$ & $\begin{array}{c}\text { Total } \\
\text { dogs }\end{array}$ \\
\hline Apparently healthy & 2 & 231 & 233 \\
Clinically suspect & 8 & 41 & 49 \\
\hline Total & 10 & 272 & 282 \\
\hline
\end{tabular}




\section{DISCUSSION}

The overall seroprevalence of $L$. infantum found in our study was $4.2 \%$ in canine shelters from Bucaramanga, Floridablanca, Girón, Piedecuesta municipalities and zero from Barrancabermeja. These results are comparable to surveys from Bogota (1.6\%) and Neiva (6.1\%) in Colombia (Rosypal et al. 2007; Zambrano et al. 2015), and reports from Argentina (6.22\%), Brazil (0.4\%), Mexico (6.1\%) and Venezuela (2.1\%) (López et al. 2012; Pacheco et al. 2013; Acosta et al. 2015; Rivas et al. 2020).

The above results describe the situation in nonendemic areas as not all infected dogs develop the disease (Baneth et al. 2008). In the case visceral leishmaniasis is starting its expansion, infected dogs may not yet have serum antibodies (Pacheco et al. 2013). This situation could be happening in the study geographic area showing low and even zero prevalence of the disease and the parasite could be widely distributed, showing a serious public health complication.

In other investigations, the prevalence was higher, as in the study of Márquez (2004) who reported a very high (39\%) seroprevalence of $L$. chagasi in dogs from Piedecuesta. Romero et al. (2008, 2009) found a seroprevalence of 68.5 and $50.2 \%$ in dogs in two occasions from the Department of Tolima and by Fernández et al. $(2002,2006)$ who found a seroprevalence of 17.2 and $19.1 \%$ for L. chagasi from Huila. Picon et al. (2020) determined $12 \%$ of visceral leishmania in dogs in the Tolima and Huila Departments. Also, our data differ from what was reported from Brazil with 10.3, 11.3, 23, and $37.3 \%$ IgG antibodies for L. infantum chagasi in dogs (Queiroz et al. 2009; Barbosa et al. 2015; Araujo et al. 2016; Fujimori et al. 2016). The local epidemiology of visceral leishmaniasis might differ widely as this difference may be associated with environmental changes, population migration, urbanization, and rural exodus. These factors may also reduce the geographic area of this parasite, increasing epidemic foci. These modifications may affect the introduction of the agent that causes leishmaniasis disease in free areas, as well as the insertion of susceptible individuals in endemic areas (DantasTorres and Brandão-Filho, 2006; Barbosa et al. 2015; Fujimori et al. 2016).

Although the general seroprevalence of L. infantum found in this study was low, other more sensitive diagnostic tests should be considered to increase the possibility of finding true positive dogs for L. infantum in the study area, considering that when performing the ELISA test some samples were inconclusive and were negative when repeating the test, according to Wolf et al. (2014), compared different diagnostic tests for L. infantum antibodies in dogs, among which the ELISA used in our study, which presented the lowest sensitivity. Therefore, some of the samples with a negative result could correspond to animals with the true presence of the disease. The lack of a gold standard is one of the main difficulties in the diagnosis of canine leishmaniasis (Wolf et al. 2014). It is important to highlight that the canine positive samples may serve as reservoirs of parasites and a source of infection of insects. This would increase the risk of disease transmission in human populations (Fernández et al. 2006; Paternina et al. 2016).
Regarding the risk factors associated with $L$. infantum canine seroprevalence, the variables gender, dog breed, age group, hair length, mosquito control, ectoparasite treatment, presence of wild animals, dogs sleeping outdoors, contact with other animals, presence of green areas/trees (yes/no), presence of mosquitoes (yes/no), knowledge of leishmaniasis were not statistically different $(\mathrm{P}>0.05)$ and odds ratio was $<1$. These data are similar to reported by Arjona et al. (2012), Barbosa et al. (2015), and Fujimori et al. (2016). Conversely, Araujo et al. (2016), found that variables mongrel breed, male gender and presence of green area/trees were the highest risk factors. In other studies, short fur was found to be the highest risk factor for the transmission of canine leishmaniasis (França et al. 2003; Moreira et al. 2003; Fujimori et al. 2016). With regard to seropositivity to $L$. infantum and the clinical signs of the disease, there were statistically significant differences. This agrees with a study carried out by Araujo et al. (2016) in dogs from the municipality of Petrolina Brazil, where clinical manifestation was significantly associated with antibodies for $L$. infantum, but other studies did not show a statistical association with clinical signs (Barbosa et al. 2015). The clinical manifestations reported in this study are similar to other reports (Queiroz et al. 2009; Barbosa et al. 2015; Araujo et al. 2016; Fujimori et al. 2016). In the present investigation, the only variable that turned out to be a risk factor was dogs sleeping outdoors. This result is similar to those reported by Martín et al. (2009), as the authors considered that dogs that sleep outside may have greater exposure to insect bites. Sandoval et al. (2006) showed the disease presence in the Department of Santander. This study is the first epidemiological description of Leishmania infantum in shelter dogs in Bucaramanga metropolitan area and Barrancabermeja municipality.

In the Bucaramanga, Floridablanca, Girón and Piedecuesta municipalities, there were appropriate conditions for the development of the biological cycle of the parasite. The area includes areas with trees and mountains and is crossed by the Oro and Surata rivers in the municipalities of Girón and Bucaramanga (EstebanMendoza et al. 2020). Mosquito vectors of leishmaniasis disease have been informed in these municipalities (Sandoval et al. (2006). Therefore, the probability of transmission of zoonotic diseases transmitted by canine vectors could increase due to the vectors' presence (mosquitoes and ticks) in the owners' homes, a frequent situation due to the successful adaptation of these arthropods in domestic areas (Otranto et al. 2009).

The diagnosing of leishmaniasis is challenging, due to a complex clinical presentation and a high proportion of asymptomatic dogs (Rosypal et al. 2007; Queiroz et al. 2009). Considering that two seropositive dogs to Leishmania did not show any signs suggestive of Leishmaniasis, this situation is a matter of public health Molina et al. (1994) and Laurenti et al. (2013) demonstrated that asymptomatic dogs can play an active role in the transmission of Leishmania, resulting in a complex situation as possible sources of transmission of the parasite. 


\section{Conclusion}

We have demonstrated the seroprevalence of $L$. infantum in canine shelters in the Andean cities of Bucaramanga, Floridablanca, Girón, and Piedecuesta, for the first time. The samples from dogs of the Barrancabermeja municipality were seronegative to $L$. infantum. Dogs sleeping outdoors showed to be the most important risk factor for L. infantum positive dogs.

\section{Acknowledgment}

Proyecto CIF CIF0308-19 UDES, Universidad de Santander, Prevalencia y factores de riesgo zoonótico de Leishmania spp. y Dirofilaria immitis en albergues caninos y áreas adyacentes ubicados en Bucaramanga y Barrancabermeja

\section{Authors' Contribution}

AAFM, JP, LEQ AR designed the study, interpreted the data, and drafted the manuscript, assisted in the collection of data and also contributed to manuscript preparation. MBM and JT were involved in interpretation of the data, drafting of the manuscript and manuscript preparation. AAFM and JP took part in preparing and critical checking this manuscript.

\section{REFERENCES}

Acosta L, Díaz R, Torres P, Silva G, Ramos M, Fattore G, Deschutter EJ and Bornay-Llinares FJ, 2015. Identification of Leishmania infantum in Puerto Iguazú, Misiones, Argentina. Revista do Instituto de Medicina Tropical de São Paulo 57: 175-176. https://doi.org/ 10.1590/S003646652015000200013

Araujo AC, Costa AP, Silva IWG, Matos NNVG, Dantas ACS, Ferreira F, Marcili A and Horta MC, 2016. Epidemiological aspects and risk factors for infection by Leishmania infantum chagasi in dogs from municipality of Petrolina, Northeastern Brazil. Veterinary Parasitology: Regional Studies and Reports 3-4: 41-48. https://doi.org/10.1016/ j.vprsr.2016.07.001

Arbeláez N, Moreno J, Murillo J, Montoya A, Robledo SM, Vélez A and Vélez ID, 2020. First report of an urban case of canine visceral leishmaniasis in the Municipality of Cali, Colombia. American Journal of Tropical Medicine and Hygiene 102: 289-293. https://doi.org/10.4269/ ajtmh.19$\underline{0515}$

Arjona-Jiménez G, Villegas N, López-Céspedes A, Marín C, Longoni SS, Bolio-González ME, Rodríguez-Vivas RI, Sauri-Arceo CH and Sánchez-Moreno M, 2012. Prevalence of antibodies against three species of Leishmania ( $\mathrm{L}$. mexicana, L. braziliensis, L. infantum) and possible associated factors in dogs from Mérida, Yucatán, Mexico. Transactions of the Royal Society of Tropical Medicine and Hygiene 106: 252-258. https://doi.org/10.1016/ j.trstmh.2011.12.003

Baneth G, Koutinas AF, Solano-Gallego L, Bourdeau P and Ferrer L, 2008. Canine leishmaniosis - new concepts and insights on an expanding zoonosis: part one. Trends in Parasitology 24: 324-330. https://doi.org/10.1016/j.pt. $\underline{2008.04 .001}$

Barbosa IR, Carlota FC and de Andrade-Neto VF, 2015. Seroepidemiological survey of canine leishmania infections from peripheral areas in Natal, Northeast Brazil. The Open Microbiology Journal 9: 43-47. https://doi.org/10.2174/ $\underline{1874285801509010043}$

Barroso A, Nevot MC, Hoyos CL, Locatelli FM, Lauthier JJ, Ruybal P, Cardozo RM, Russo PD, Vassiliades CN, Mora
MC, Estévez JO, Hashiguchi Y, Korenaga M, Basombrío MA and Marco JD, 2015. Genetic and clinical characterization of canine leishmaniasis caused by Leishmania (Leishmania) infantum in northeastern Argentina. Acta Tropica 150: 218-223. https://doi.org/ 10.1016/j.actatropica.2015.08.007

Bowman D, 2014. Georgis' Parasitology for Veterinarians, 10th ed. Elsevier, St. Louis, Missouri, USA, pp: 254.

Cáceres AV, 2020. Reporte de caso, Leishmaniasis en paciente canino (Canis Lupus Familiaris) de la raza Pug en la Clínica Veterinaria Animales de Compañía de La Universidad Cooperativa De Colombia. Universidad Cooperativa De Colombia Facultad De Medicina Veterinaria Y Zootecnia. Tesis de grado Medicina Veterinaria.

Dantas-Torres F, 2009. Canine leishmaniosis in South America. Parasites \& Vectors 2: S1. https://doi.org/ 10.1186/1756-3305-2-S1-S1

Dantas-Torres F, 2007. The rol of dogs as reservoirs of Leishmania parasites, with emphasis on Leishmania (Leishmania) infantum and Leishmania (Viannia) braziliensis. Veterinary Parasitology 149: 139-146. http://dx.doi.org/10.1016/j. vetpar.2007.07.007

Dantas-Torres F and Brandao-Filho SP, 2006. Visceral leishmaniasis in Brazil: Revisiting paradigms of epidemiology and control. Revista do Instituto de Medicina Tropical de São Paulo 48:151-156. http://dx.doi.org/ 10.1590/S0036-46652006000300007

de Almeida ME, Spann DR and Bradbury RS, 2020. Leishmania infantum in US-Born dog. Emergin Infectious Diseases 26: 1882-1884. https://doi.org/10.3201/eid2608.200149

Esteban-Mendoza MV, Arcila-Quiceno V, Albarracín-Navas J, Hernandez I, Flechas- Alarcon MC and Morchon R, 2020. Current situation of the presence of Dirofilaria immitis in dogs and humans in Bucaramanga, Colombia. Frontiers in Veterinary Science 7: 488. https://doi.org/10.3389/fvets. 2020.00488

Feliciangeli MD, Delgado O, Suarez B and Chiurillo MA, 2005. The burden of the Leishmania chagasi/infantum infection in a closed rural focus of visceral leishmaniasis in Lara state, west-central Venezuela. Tropical Medicine \& International Health 10: 444-449. https://doi.org/10.1111/ j.1365-3156.2005.01408.x

Fernández MJ, Charry CT, Bello GF, Escobar JE, Lozano CA, Ayala SM, Nicholls RS, Vargas J, Moncada LI, Corredor AA and López MC, 2002. Prevalencia de Leishmaniosis Visceral Canina en Municipios de HuilaColombia. Revista Salud Pública 4: 278-285.

Fernández J, Bello F, López MC, Moncada LI, Vargas JJ, Ayala MS, Nicholls RS and Lozano CA, 2006. Seroprevalencia de leishmaniosis visceral canina en la comuna 8 de Neiva y en cuatro municipios de Huila, Colombia. Biomédica 26: 121130. https://doi.org/10.7705/biomedica.v26i1.1506

França-Silva JC, da Costa RT, Siqueira AM, Machado-Coelho GL, da Costa CA, Mayrink W, Vieira EP, Costa JS, Genaro $\mathrm{O}$ and Nascimento E, 2003. Epidemiology of canine visceral leishmaniosis in the endemic area of Montes Claros Municipality, Minas Gerais State, Brazil. Veterinary Parasitology 111:161-173. https://doi.org/10.1016/s03044017(02)00351-5

Fujimori M, Almeida ADBPF, de Dias ÁFLR, Rodrigues JY, Nakazato L, Madeira MDF and Sousa VRF, 2016 Prevalence and associated factors of canine visceral leishmaniasis in an endemic area of Mato Grosso, Brazil. Acta Scientiae Veterinariae 44: 1424. https://doi.org/ 10.22456/1679-9216.81301

Gaskin AA, Schantz P, Jackson J, Birkenheuer A, Tomlinson L, Gramiccia M, Levy M, Steurer F, Kollmar E, Hegarty BC, Ahn A and Breitschwerdt EB, 2002. Visceral leishmaniasis in a New York foxhound kennel. Journal of Veterinary 
Internal Medicine 16: 34-44. https://doi.org/10.1892/08916640(2002)016<0034:vliany >2.3.co;2

Gobernación de Santander, 2017. Municipios del Departamento de Santander. Available at: http://www.santander. gov.co/index.php/atencion-al-ciudadano/directorios/ directorio-municipios

Herrera G, Higuera A, Patiño LH, Ayala MS and Ramírez JD, 2018. Description of Leishmania species among dogs and humans in Colombian Visceral Leishmaniasis outbreaks. Infection Genetics and Evolution 64: 135-138. https://doi.org/10.1016/j.meegid.2018.06.023

Herrera G, Castillo A, Ayala MS, Flórez C, Cantillo-Barraza O and Ramirez JD, 2019. Evaluation of four rapid diagnostic tests for canine and human visceral Leishmaniasis in Colombia. BMC Infectious Diseases 19: 747. https://doi.org/10.1186/s12879-019-4353-0

Instituto de Hidrología, Meteorología y Estudios Ambientales IDEAM, 2019. Boletín Climatológico Mensual, Available at: https://n9.cl/18hh.

Laurenti MD, Rossi CN, da Matta VL, Tomokane TY, Corbett CE, Secundino NF, Pimenta PF and Marcondes M, 2013. Asymptomatic dogs are highly competent to transmit Leishmania (Leishmania) infantum chagasi to the natural vector. Veterinary Parasitology 196: 296-300. https://doi.org/10.1016/j.vetpar.2013.03.017

Le Pape P, 1992. Écoépidémiologie de la leishmaniose a Leishmania infantum = L. chagasi dans la plaine des caraïbes (Colombie): corrélation vecteur et réservoir canin. Montpellier: Université de Montpellier.

López-Céspedes A, Longoni SS, Sauri-Arceo CH, SánchezMoreno M, Rodríguez-Vivas, R I, Escobedo-Ortegón FJ, Barrera-Pérez MA, Bolio-González ME and Marín C, 2012. Leishmania spp. epidemiology of canine leishmaniasis in the Yucatan Peninsula. Scientific World Journal 2012: 945871. https://doi.org/10.1100/2012/945871

Márquez LL, 2004. Prevalencia de infección por Leishmania chagasi en la población canina (LVC) de la vereda Guatiguará de Piedecuesta, Santander (tesis). Bucaramanga: Universidad Industrial de Santander.

Martín-Sánchez J, Morales-Yuste M, Acedo-Sánchez C, Barón S, Díaz V and Morillas-Márquez F, 2009. Canine leishmaniasis in southeastern Spain. Emerging Infectious Diseases 15: 795-798. https://doi.org/10.3201/eid1505. 080969

Meleau L, Hnilico K, 2006. Small animal dermatology: a color atlas and therapeutic guide. 2nd Ed, Elseviers, St Louis, Missouri, USA, pp: 154.

Ministerio de salud de Colombia 2019. Subdirección de salud ambiental cobertura de vacunación antirrábica por municipio Colombia 2019. Disponible en: https://www. minsalud.gov.co/sites/rid/Lists/BibliotecaDigital/RIDE/VS/ PP/A/cobertura-vacunacion-antirrabica-municipio-2019.pdf

Molina R, Amela C, Nieto J, San-Andrés M, González F, Castillo JA, Lucientes J and Alvar J, 1994. Infectivity of dogs naturally infected with Leishmania infantum to colonized Phlebotomus perniciosus. Transactions of the Royal Society of Tropical Medicine and Hygiene 88: 491493. https://doi.org/10.1016/0035-9203(94)90446-4

Moreira Jr ED, de Souza VMM, Sreenivasan M, Lopes NL, Barreto RB and de Carvalho LP, 2003. Peridomestic risk factors for canine leishmaniasis in urban dwellings: New findings from a prospective study in Brazil. American Journal of Tropical Medicine and Hygiene 69: 393-397. https://doi.org/10.4269/ajtmh.2003.69.393

Otranto D, Dantas-Torres F and Breitschwerdt EB, 2009. Managing canine vector-borne diseases of zoonotic concern: part one. Trends in Parasitology 25: 157-163.

Pacheco AD, Marcia DL, Marçal V, Lima Félix De Tomokane TY and Marcondes M, 2013. Leishmania sp. infection in dogs from Florianópolis. Braz. Journal of Veterinary
Research and Animal Science 50: 220-225 https://doi.org/10.11606/issn.1678-4456.v50i3p220-225

Paternina LE, Díaz-Olmos Y, Paternina-Gómez M, CarrilloBonilla L, Vélez I and Bejarano E, 2016. Detección de anticuerpos anti-leishmania (trypanosomatidae) en poblaciones caninas del departamento de sucre, Colombia. Acta Biológica Colombiana 21: 183-188. https://dx.doi.org/ 10.15446/abc.v21n1.48845

Picon Y, Almario G, Rodríguez V and Garcia, NV, 2020. Seroprevalence, clinical, and pathological characteristics of canine leishmaniasis in a central region of Colombia. Journal of Veterinary Research 64: 85-94. https://doi.org/10.2478/jvetres-2020-0011

Queiroz PV, Monteiro GR, Macedo VP, Rocha MA, Batista LM, Queiroz JW, Jerônimo SM and Ximenes MF, 2009. Canine visceral leishmaniasis in urban and rural areas of Northeast Brazil. Research in Veterinary Science 86: 267-273. https://doi.org/10.1016/j.rvsc.2008.07.014.E

Rivas AK, Alcover MM, Martínez-Orellana P, MontserratSangrà $S$, Nachum-Biala $Y$, Fisa R, Riera $C$, Baneth $G$ and Solano-Gallego L, 2020. Serological and molecular survey of Leishmania infection in dogs from Venezuela. Veterinary Parasitology: Regional Studies and Reports 21: 100420. https://doi.org/10.1016/j.vprsr.2020.100420

Rivero-Rodríguez M, Rodríguez-Jiménez J, Pérez-Doria A and Bejarano E, 2018. Isolation of Leishmania infantum from Canis familiaris in an urban area of the colombian Caribbean. Revista de Investigaciones Veterinarias del Perú 29: 923-930. https://doi.org/10.15381/rivep.v29i3.13708

Rivero-Rodríguez M, Pérez-Doria A and Bejarano-Martínez E, 2020. Leishmaniasis visceral en población infantil y canina en área urbana del municipio de Ovejas, Colombia. Ciencia e Innovación en Salud e95: 357-367. https://doi.org/10.17081/innosa.95

Romero M, López M and Sanchez J, 2009. Búsqueda activa de casos de leishmaniasis visceral zoonótica en población infantil indígena y canina colombiana. Revista salud pública 11: 944-951.

Romero M, López M, Echeverry M and Rivas Favio, 2008. Leishmaniasis Visceral Canina: Pruebas diagnósticas no identifican estados reales de la infección. Revista Salud Pública 10: 290-298.

Rosypal JA, Cortes-Vecino JA, Gennari SM, Dubey, JPR.R, Tidwell, DS and Lindsay DS, 2007. Serological survey of Leishmania infantum and Trypanosoma cruzi in dogs from urban areas of Brazil and Colombia. Veterinary Parasitology 149: 172-177. https://doi.org/10.1016/j. vetpar.2007.08.004

Sandoval CM, Gutiérrez R, Cárdenas R and Ferro C, 2006. Especies de género Lutzomyia (Psychodidae, Phlebotominae) en áreas de transmisión de leishmaniasis tegumentaria y visceral en el departamento de Santander, en la cordillera oriental de los Andes colombianos. Biomédica 26: 218-227. https://doi.org/10.7705/biomedica.v26i1.1515

Schaut RG, Robles-Murguia M, Juelsgaard R, Esch KJ, Bartholomay LC, Ramalho-Ortigao M and Petersen CA, 2015. Vector borne transmission of leishmania infantum from Hounds, United States. Emerging Infectious Diseases 21: 2209-2212. https://doi.org/10.3201/eid2112.141167

SPSS, 2012. Statistics for Windows, Version 21. 0. IBM Corporation, Armonk, New York.

Thrusfield M, 2007. Veterinary Epidemiology, 3rd ed. Blackwell Science, Oxford, UK, pp: 229-233.

Travi BL, Palma GI and Vélez ID, 1992. Epidemiological assessment of a visceral Ieishmaniasis focus in Córdoba, Colombia: a first step towards disease control. Reporte Final WHO, ID 890419.

Travi BL, Tabares CJ, Cadena H, Ferro C and Osorio Y, 2001. Canine visceral leishmaniasis in Colombia: relationship between clinical and parasitologic status and infectivity for 
Int J Vet Sci, 2022, 11(2): 175-182.

sand flies. American Journal of Tropical Medicine and Hygiene 64: 119-124. https://doi.org/10.4269/ajtmh.2001. $\underline{64.119}$

Wolf D, Failing K, Taubert A and Pantchev N, 2014. Serological diagnosis of canine leishmaniosis: comparison of three commercially available tests. Parasitology Research 113: 1997-2002. https://doi.org/10.1007/s00436-014-3865-1
Zambrano-Hernandez, P, Ayala-Sotelo MS, Fuya-Oviedo P, Montenegro-Puentes CA, Aya-Vanegas N, AguileraJaramillo G, Blázquez $\mathrm{O}$, Becerra $\mathrm{S}$, Lozano $\mathrm{C}$, RojasGarcía M and Rodríguez-Toro G, 2015. Brote urbano de leishmaniasis visceral en Neiva, Colombia. Revista Salud Pública 17: 514-527. https://dx.doi.org/10.15446/rsap. $\underline{\mathrm{v} 17 \mathrm{n} 4.44663}$ 